\title{
Scales and instruments for measuring self-esteem in adolescents and young adults
}

\author{
Escalas e Instrumentos para evaluar autoestima en adolescentes y jóvenes adultos
}

\author{
Dulce M. Ochoa-Corral ${ }^{a}$, Guadalupe Campos-Valdez ${ }^{b}$, Alberto Gómez-Zarco , ${ }^{c}$ Alejandra
} Lima-Quezada ${ }^{d}$

\begin{abstract}
:
Self-esteem is an evaluation the individual makes about themself, being classified as positive or negative. To accomplish this, psychology has proposed, use valid and reliable measuring instruments in the Mexican population since there is a primary need to understand the different levels of self-esteem in individuals. The study's objective was composing a review of validated scales and psychological instruments in the Mexican population on Self-esteem in adolescents and young adults from 15 to 25 years old. The collection of information was made through databases such as PUBMED, Redalyc, Google Academic, Scielo, and Dialnet. The descriptors were Self-esteem, adolescence, youth, and instruments of psychological evaluation. Ninety-six articles were found, which only 5 of them fulfill the criteria. The results reflect five scales and instruments that measure self-esteem in Mexican adolescents and young adults, the application of these instruments fluctuates from 14 to 51 years and presents a reliability $>0.70$. It is concluded that in Social Sciences and Psychology, the application of instruments provides objective measures for a variety of problems to deal with it. For this reason, valid and reliable self-esteem scales in the Mexican population may smooth the progress of the selection depending on subscales or factors that the psychologist or researcher wants to address individually or in a group.
\end{abstract}

\section{Keywords:}

Self-esteem, adolescence, youth, psychological assessment instruments, validation for Mexican population

\section{Summary:}

La autoestima es una evaluación que el individuo realiza sobre sí mismo, siendo catalogada como positiva o negativa. Para ello, la psicología ha propuesto utilizar instrumentos de medición válidos y confiables en la población mexicana, puesto que, existe una necesidad primordial para comprender la existencia de distintos niveles de autoestima. El objetivo del estudio fue realizar una revisión de escalas e instrumentos de evaluación psicológica validados en población mexicana sobre autoestima en adolescentes y jóvenes adultos de 15 a 25 años. El recabado de información se realizó mediante bases de datos como PUBMED, Redalyc, Google Académico, Scielo y Dialnet. Los descriptores de autoestima, adolescencia, juventud e instrumentos de evaluación psicológica. Se encontraron 96 artículos, los cuales sólo 5 cumplieron con los criterios de selección. Los resultados reflejan 5 escalas e instrumentos que miden la autoestima en los adolescentes y jóvenes adultos mexicanos, la aplicación de dichos instrumentos oscila entre 14 a 51 años, y presentan una confiabilidad >0.70. Se concluyó, que en Ciencias Sociales y Psicología, la aplicación de instrumentos aporta medidas objetivas de diversas problemáticas a tratar. Por esta razón, las escalas de autoestima válidas y confiables en población mexicana podrán facilitar la elección dependiendo de las subescalas o factores que desea abordar el/la psicólogo/a o investigador/a de manera individual o grupal.

\section{Keywords}

Autoestima, adolescencia, juventud, herramientas de evaluación psicológica, validación para la población mexicana

\section{INTRODUCTION}

Self-esteem is a positive attitude of the individual with himself. When it occurs at high levels, it indicates perceiving yourself as a competent being. The subject thinks it is essential; he values himself for what he represents, he does not show fear of respecting himself (Rosenberg, 1965; Riso, 2006). Instead, low levels can lead to negative attitudes in the subject (Montoya \& Sol, 2001). Furthermore, it symbolizes the possibility of taking responsibility for oneself, leading to a sense of self-worth nurtured both at home and school and/or work (Raffini, 1998). In this way, it has been considered that this variable can be defined as an evaluation that the individual generates from himself, expressing a positive or negative perspective and seeks

\footnotetext{
a Universidad de Sonora, https://orcid.org/0000-0001-9383-5370, Email: $\underline{\text { d_ochoa10@ hotmail.com }}$

b Universidad de Sonora, https://orcid.org/0000-0003-2328-3384, Email: gpecampos03@ hotmail.com

c Universidad de Sonora, https://orcid.org/0000-0001-7612-3304, Email: psic.albertogomez@gmail.com

${ }^{\mathrm{d}}$ Corresponding author, Universidad Autónoma del Estado de Hidalgo, https://orcid.org/0000-0001-8768-7340, Email:
} li227408@uaeh.edu.mx 
to point to what he feels capable of or successful. In this sense, self-esteem can be considered subjective since the individual may or may not approve of such perception (Coopersmith, 1976; Serrano, 2013).

\section{Self-esteem as a mediator of risk and protective factors}

A study conducted by Jimenez (2011) found that self-esteem has a mediating role in adolescents' possible use of substances. It is suggested that it has a relationship with family functioning because the positive or negative family climate can enhance or inhibit the positive assessments of the adolescent in different aspects of his life, either socially or psychologically. Such evaluations are considered to be significant predictors of substance use.

Similarly, in school and adolescent age, self-esteem plays a crucial role in health, well-being, and behavior. For example, in teenage women, there have been lower numbers of pregnancies at an early age, while adolescent men with low self-esteem increase behavioral enhancers that negatively affect their health, such as tobacco, alcohol, and different addictive substances (Cogollo, Campo-Arias, \& Herazo, 2015).

Low self-esteem is linked to various risk factors in adolescence, such as unhealthy habits, criminal behaviors, economic scarcity, cognitions or suicide attempts, and psychiatric symptoms or disorders of depression (Chen, Hong, \& Yang, 2010; Orth \& Robins, 2008; Trzesniewski et al., 2006). Otherwise, high self-esteem is associated with protective factors, such as preventing suicidal thoughts and depressive disorders (Ceballos-Ospino et al., 2015). In addition, people with high self-esteem tend to be more structured in the student area and show greater control over stressful situations (Dumont \& Provost, 1999; Gázquez, Pérez, Ruiz, Miras, \& Vicente, 2006).

\section{Importance of measurement}

According to Arias (1991), there is a strong need to use measurement instruments in psychology in current psychology, this from the increase of studies carried out there. However, this can lead to indiscriminate use of those that exist and even perform inadequate construction and validation processes that could lead to unforgivable errors in the development of science. The moment must be confronted with a practical sense, but with sufficient technical preparation, the fact requires the measurement in psychology to find its right place.

However, to understand the importance of measuring selfesteem, it is considered relevant to realize that at different levels at which it can be found, each individual can react differently to similar situations. Similarly, people with low levels commonly feel unsafe with activities they do daily, which causes them to be dissatisfied with their ways of performing these tasks and the different goals that are proposed. (Mendez, 2015; Ochoa et al., 2018). For this reason, depending on the author and the characteristics of the population, self-esteem can be measured in one way or another, reaching a point at which one or the other could not be chosen as more suitable for the general measurement of it.

A psychometric scale or instrument is distinguished by determining the construct by numerical scores resulting from applying a series of reagents to specific people. The scale may consist of a list of questions or statements, each of the two response options such as "yes" and "no," also called dichotomic. In other cases, scales can be with more than three response options; this scale is called type Likert. The final scores of the instrument can be obtained by adding the responses of each reagent will indicate the degree of according to the construct established in each of the participants (Montero, 2000; Muñiz \& Fonseca-Pedrero, 2019).

The basic properties of a measurement on an instrument are validity and reliability (Carmines \& Zeller, 1987). The validity of an instrument is characterized by the level of belonging of the interpretations resulting from the application of a questionnaire, i.e. that an instrument will be valid if it measures that it was established to measure it. Messick $(1989,1996)$. On the other hand, reliability means that conducting a study to a specific population assessed on different occasions with the same instrument will always produce similar results; however, reliability cannot ensure that the results will be accurate to those established. It should be noted that a scale or instrument may be reliability, however, it may not be valid for a specific sample or population (Babbie, 2000).

Hernandez and Fernández (2000) mention that the lower the levels of variability of the responses, in other words, that each of the reagents present similar responses, the higher the reliability. Reliability coefficient values range from 0 to 1 , where the range of 0.70 to 1.00 are considered acceptable levels of reliability (Sierra, 2001).

In contrast, the Omega coefficient is another functional option used in the Social Sciences to demonstrate the reliability of a scale and evaluation instrument, where they expose as permissible reliability indices a range of 0.70 and 0.90 (CampoArias \& Oviedo, 2008; Joreskog, 1971; McDonald, 1999).

The study's objective is to review the scales and instruments of psychological evaluation validated with the Mexican population on self-esteem in adolescents and young adults aged 15 to 25 .

\section{METHOD}

The method focused on conducting a systematic search that would allow a better order, flow, and description of the revised documents. First, it began with studies published by Mexican and foreign researchers working on self-esteem in adolescents and young adults. The collection of information was then carried out through databases of pubmed, redalyc, academic google, scielo and dialnet, among others. The search was carried out with the descriptors of self-esteem, adolescence, youth and psychological evaluation instruments, where 96 articles were found that were analyzed to identify the instruments used in these studies on self-esteem, of which only 5 were selected because they had the selection criteria, which were: instruments that evaluated the self-esteem and subscales of the same, that they were aimed at adolescents and young adults, who had a validation in the Mexican population, whose reliability is greater than 0.70 and finally that the instrument could be applied in people in an age range of 15 to 25 years.

\section{RESULTS}

This bibliographic review analyzed 96 publications. Five scales and instruments were found that measured self-esteem in Mexican adolescents and young adults. The application of these instruments ranges from 14 to 51 years of age and has higher reliability than 0.70 .

The selected scales and instruments are as follows: 


\section{Adolescent self-esteem test}

Pope, Mchale, and Craighead (1988) created the adolescent self-esteem test. The validation for the Mexican population on a case-by-case basis, was performed by Hernández-Guzmán (2001).

The scale consists of 21 reagents ("I like the way I am"), with five response options "always," "usually," "sometimes," "rarely," and "never," to evaluate cognitions about itself, cognitions of competence, family relationship, and anger, with a reliability rate of $\alpha=0.88$, high scores indicate greater selfesteem.

Table 1.

Name of the scale or instrument, authors and reliability.

\begin{tabular}{|c|c|c|c|}
\hline $\begin{array}{l}\text { Name of scale } \\
\text { or instrument }\end{array}$ & $\begin{array}{l}\text { Authors and } \\
\text { year of } \\
\text { validation for } \\
\text { the Mexican } \\
\text { population }\end{array}$ & $\begin{array}{c}\text { Authors } \\
\text { and year of } \\
\text { validation } \\
\text { for other } \\
\text { Spanish- } \\
\text { speaking } \\
\text { populations }\end{array}$ & Reliability \\
\hline $\begin{array}{l}\text { Adolescent } \\
\text { self-esteem } \\
\text { test by Pope, } \\
\text { Mchale y } \\
\text { Craighead } \\
(1988)\end{array}$ & $\begin{array}{l}\text { Caso \& } \\
\text { Hernández- } \\
\text { Guzmán } \\
\text { (2001) } \\
\text { Caso, } \\
\text { Hernández- } \\
\text { Guzmán, \& } \\
\text { González- } \\
\text { Montesinos } \\
\text { (2011) }\end{array}$ & $\begin{array}{l}\text { Tovar \& } \\
\text { Zavarce } \\
(1992)\end{array}$ & $\alpha=0.88$ \\
\hline $\begin{array}{l}\text { Modified self- } \\
\text { esteem scale } \\
\text { for teens by } \\
\text { Andrade y Pick } \\
\text { (1986) }\end{array}$ & Medina (1998) & $\begin{array}{l}\text { Guido, } \\
\text { Mújica, \& } \\
\text { Gutiérrez } \\
\text { (2011) }\end{array}$ & $\alpha=0.76$ \\
\hline $\begin{array}{l}\text { Self-esteem } \\
\text { scale by Reidl } \\
\text { (1981) }\end{array}$ & $\begin{array}{l}\text { Alcántar, } \\
\text { Villatoro, } \\
\text { Hernández, \& } \\
\text { Fleiz (1998) }\end{array}$ & $\begin{array}{l}\text { Loli, Arias, } \\
\text { Carpio, } \\
\text { Arce, Reyes } \\
\text { \& Anyaco } \\
\text { (2014) }\end{array}$ & $\begin{array}{l}\alpha=0.70 a \\
0.76 .\end{array}$ \\
\hline $\begin{array}{l}\text { Coopersmith's } \\
\text { self-esteem } \\
\text { scale by } \\
\text { Coopersmith } \\
(1967)\end{array}$ & $\begin{array}{l}\text { Lara-Cantú, } \\
\text { Verduzco, } \\
\text { Acevedo, \& } \\
\text { Cortés (1993) }\end{array}$ & $\begin{array}{l}\text { Brickman, } \\
\text { Segure, \& } \\
\text { Solar (1989) }\end{array}$ & $\alpha=0.81$ \\
\hline $\begin{array}{l}\text { Rosenberg's } \\
\text { self-esteem } \\
\text { scale by } \\
\text { Rosenberg } \\
(1965)\end{array}$ & $\begin{array}{l}\text { D., Jurado, } \\
\text { Jurado, Lopez, } \\
\text { \& Querecalú } \\
\text { (2015) }\end{array}$ & $\begin{array}{l}\text { Rojas- } \\
\text { Barahona, } \\
\text { Zegers, \& } \\
\text { Förster } \\
\text { (2009) }\end{array}$ & $\alpha=0.79$ \\
\hline
\end{tabular}

\section{Modified self-esteem scale for teens}

The scale of self-esteem modified for teenagers (EAMA) created by Andrade y pick (1986) and validated for the Mexican population by medina (1998) measures the feeling of a comprehensive assessment that the adolescent presents about himself.
The scale consists of 55 reagents ("I feel physical"), with five options of response from 1 to 5 "I feel very good," "little good," "neither good nor bad," "not bad," and "very bad," to evaluate cognitions on itself, cognitions of competence, family relationship, and anger, with reliability rates of $\alpha=0.76$.

\section{Self-esteem scale}

Reidl (1981) created the Self-esteem Scale and was validated for the Mexican population by Alcántar, Villatoro, Hernández, and Fleiz (1998), which measures the subject's assessment of individual and social aspects with himself.

The scale consists of 13 reagents ("I am a person with many qualities"), with three response options from 1 to 3 , to evaluate individual aspects and social aspects, with reliability rates of $\alpha=0.76$ and 0.70 .

\section{Coopersmith's self-esteem scale}

The inventory of self-esteem created by Coopersmith (1967) and validated by Lara-Cantú, Verduzco, Acevedo y Cortés (1993) measures personal judgment of self-worth and consists of 25 reagents with dichotomous responses "yes" and "no," with reliability rates of $\alpha=0.81$.

\section{Rosenberg's self-esteem scale}

The scale of self-esteem created by Rosenberg (1965) and validated for the Mexican population per Jury et al. (2015).

Is a scale made up of 10 reagents with likert-scale response options, looking to explore self-esteem individually, such as feelings of personal value and self-respect, with reliability rates of $\alpha=0.79$.

Both Rosenberg and each scale above consist of specific values to confirm their validity levels, objectives and the other factors that make up them, as can be seen in Table 1 and 2 .

\section{DISCUSSION}

In this article, publications of psychological evaluation scales and instruments with validation in the Mexican population on self-esteem in adolescents and young adults aged 15 to 25 years were reviewed, the results reflected that the selected scales and instruments meet to measure the levels of self-esteem as cognitive, physical and social aspects of the person with themselves, have validation in the Mexican population, reliability rates range from 0.70 to 0.88 , and their age ranges for their application are around 14 to 51 years.

The instruments have the selection criteria, since Sierra (2001) mentions that the reliability levels of an instrument must be greater than 0.70 to be valued as acceptable, to be applied in a specific population. Similarly, Schmitt (1996) states that the level of reliability required in an instrument must be more than 0.70 to be used in a certain population. Together, Martínez (1995) refers that a scale or instrument is considered suitable for use at the time it correctly fulfills the purpose for which it was performed. The validity of the measuring instruments is governed by the objective set because not all evaluate the same properties and is established on the basis of the usefulness of their application. This means that the selected instruments are valid and reliable to be applied in the population of Mexican adolescents and young adults to assess the degree of self-esteem individually or in groups. 
Table 2.

Objective, subscales, and properties of the scale or instrument.

\begin{tabular}{|c|c|c|}
\hline $\begin{array}{l}\text { Name of scale } \\
\text { or instrument }\end{array}$ & Objective & Subscales and Properties \\
\hline $\begin{array}{l}\text { Adolescent } \\
\text { self-esteem } \\
\text { test by Pope, } \\
\text { Mchale y } \\
\text { Craighead } \\
(1988)\end{array}$ & $\begin{array}{l}\text { Evaluate the } \\
\text { levels of self- } \\
\text { esteem in } \\
\text { adolescents. }\end{array}$ & $\begin{array}{l}\text { Cognitions about himself, } \\
\text { Cognitions of } \\
\text { competence, Family } \\
\text { relationship and Anger. } \\
\text { Likert-type scale with } 5 \\
\text { response options. } \\
\text { Self-applied } \\
21 \text { items }\end{array}$ \\
\hline $\begin{array}{l}\text { Modified self- } \\
\text { esteem scale } \\
\text { for teens by } \\
\text { Andrade y Pick } \\
\text { (1986) }\end{array}$ & $\begin{array}{l}\text { Evaluate the } \\
\text { feeling of } \\
\text { integral value } \\
\text { that the } \\
\text { adolescent } \\
\text { presents of } \\
\text { himself. }\end{array}$ & $\begin{array}{l}\text { Physical, Moral, } \\
\text { Emotional, Relationships } \\
\text { as Friend, Student and } \\
\text { Child. } \\
\text { Likert-type scale with } 5 \\
\text { response options. } \\
\text { Self-applied } \\
55 \text { items }\end{array}$ \\
\hline $\begin{array}{l}\text { Self-esteem } \\
\text { scale by Reidl } \\
(1981)\end{array}$ & $\begin{array}{l}\text { Evaluate the } \\
\text { assessment } \\
\text { that the subject } \\
\text { makes of the } \\
\text { individual and } \\
\text { social aspects } \\
\text { with himself. }\end{array}$ & $\begin{array}{l}\text { Individual aspects and } \\
\text { social aspects. } \\
\text { Likert-type scale with } 3 \\
\text { response options. } \\
\text { Self -applied } \\
13 \text { items }\end{array}$ \\
\hline $\begin{array}{l}\text { Coopersmith's } \\
\text { self-esteem } \\
\text { scale by } \\
\text { Coopersmith } \\
\text { (1967) }\end{array}$ & $\begin{array}{l}\text { Evaluate } \\
\text { personal } \\
\text { judgment of } \\
\text { self-worth. }\end{array}$ & $\begin{array}{l}\text { Dichotomous scale with } 2 \\
\text { response options. } \\
\text { Self-applied } \\
25 \text { items }\end{array}$ \\
\hline $\begin{array}{l}\text { Rosenberg's } \\
\text { self-esteem } \\
\text { scale by } \\
\text { Rosenberg } \\
\text { (1965) }\end{array}$ & $\begin{array}{l}\text { Evaluate the } \\
\text { individual self- } \\
\text { steem, such as } \\
\text { feelings of } \\
\text { personal worth } \\
\text { and self- } \\
\text { respect. }\end{array}$ & $\begin{array}{l}\text { Likert-type scale with } 4 \\
\text { response options. } \\
\text { Self-applied } \\
10 \text { items }\end{array}$ \\
\hline
\end{tabular}

According to the various searches carried out of the term selfesteem, the traditional definition has been set out and as proposed by Rosenberg (1965) and Riso (2006). From there we have tried to better describe the concept, however, for now, there is no unanimous position as to what self-esteem is. Still, different authors have concluded that there are 4 different ways to define self-esteem. The first, focuses from the idea that the "himself" can be considered as an object of attention to the subject, the second form, is shown as the difference between this real "himself" and the ideal and, the third way is the one that seeks to focus on the psychological part that an individual shows of "himself". Finally, Wells and Marwell (1976) stated that self-esteem can be understood as an additional component of the personality of individuals (Ortega, Mínguez, \& Rodes, 2001). The complexity of measuring self-esteem and even more so working as a specific factor in various individuals, which certainly requires a theoretical clarification of behavior.

This review has presented a series of studies that, using a quantitative methodology, sought to consider different areas that encompass the conceptualization of self-esteem. As noted in Table 1, most studies use a similar design and quantitative methodology, with more abundant work in the subscales that make up it.

\section{CONCLUSIONS}

The application of evaluation tools is of paramount importance in the area of Social Sciences and specifically in Psychology, since, by using them you can obtain objective measures of various problems to be addressed, in this case focusing on the self-esteem of adolescents and young adults. To this end, this bibliographic review article was carried out, which sets out different scales and instruments valid and reliable for the Mexican population, in order to determine the levels of selfesteem. In addition, the protective and risk factors that relate to the self-esteem of said population are raised, which can be identified by means of the scales presented, according to the subscales or factors that measure each of them, thus facilitating the choice depending on the specific problem that the psychologist or researcher wants to address.

As is well known, within digital libraries there is a huge collection of information and instruments that can be easily accessed, however, when searching for information for a very specific population and/or reduced the search for specific instruments can become a laborious or quite complicated process. Therefore, further deepening of the study of population-specific variables would be relevant, in this particular case, the formulation of new instruments that measure self-esteem would be desirable to further promote the implementation of theoretical and methodological designs that not only support what has already been found by authors such as Coopersmith or Rosenberg.

For this reason, it should be emphasized again that self-esteem in adolescent ages requires specificity in its conceptualization and counterparty study with the frequent study of self-esteem in childhood.

Finally, it is necessary to emphasize that the problem of lack of instruments (validated in Mexican population) is a phenomenon that causes a decrease in the field of work for various professionals in the area of social sciences, the understanding of the limitation caused by the lack of such instruments or the limitations caused by translations and retranslations, give an opening to know what changes can be generated from there and provide an area of opportunity.

\section{REFERENCES}

Alcántar, E. N., Villatoro, J. A., Hernández, R., Suhaili, A. \& Fleiz, C. (1998). Relación entre entendimiento escolar y autoestima en adolescentes. La Psicología Social en México, 7, 369-374.

Andrade, P. \& Pick, W. (1986). Una escala de autoconcepto para niños. Trabajo presentado en el II Congreso Mexicano de Psicología Social. La trinidad Tlaxcala.

Arias, G. (1991). La medición en psicología: una reflexión impostergable. Revista Cubana de Psicología, 8(2), 93-100.

Babbie, E. (2010). The practice of social research. California: Wadsworth. 
Brickman, H., Segure, T., \& Solar, M. I. (1989). Adaptación, estandarización y elaboración de normas para el inventario de autoestima de coopersmith. Revista chilena de psicología, 10(1), 63-71.

Campo-Arias, A. \& Oviedo, H. C. (2008). Propiedades psicométricas de una escala: La consistencia interna. Revista de Salud Pública, 10(5), 831-839.

Carmines, E. \& Zeller, R. (1987). Reliability and validity assessment. USA: Sage

Caso, J. \& Hernández-Gúzman, L. (2001). ¿Son contextos medioambientales los que definen las dimensiones de la autoestima en niños y adolescentes?. Revista Mexicana de Psicología, 18(1), 229-337.

Caso, N. J., Hernández-Guzmán, L., \& González-Montesinos, M. (2011). Prueba de Autoestima para Adolescentes. Universitas Psychologica, 10(2), 535-543.

Chen, C., Hong, Y. \& Yang, S. (2010). Relationships among adolescents' life events, self-esteem, depression and suicide ideation. Chinese Journal of Clinical Psychology, 18(2), 190-191.

Cogollo, Z., Campo-Arias, A. \& Herazo, E. (2015). Escala de Rosenberg para autoestima: consistencia interna y dimensionalidad en estudiantes de Cartagena, Colombia. Psychologia: Avances de la Disciplina, 9(2), 61-71.

Coopersmith, S. (1967). The antecedents of self-esteem. Consulting Psychologist Press.

Dumont, M. y Provost, M. A. (1999). Resilience in adolescents: Protective role of social support, coping strategies, selfesteem, and social activities on experience of stress and depression. Journal of youth and adolescence, 28(3), 343363.

Gázquez, J. J., Pérez, M. C., Ruiz, M. I., Miras, F., \& Vicente, F. (2006). Estrategias de aprendizaje en estudiantes de enseñanza secundaria obligatoria y su relación con la autoestima. International Journal of Psychology and Psychological Therapy, 6, 51-62.

Guido, P., Mújica, A. \& Gutiérrez, R. (2011). Diferencias en el autoconcepto por sexo en la adolescencia: construcción y validación de un instrumento. Liberabit, 17(2), 139-146.

Hernández, R. \& Fernández, C. (2000). Metodología de la investigación. México: McGraw-Hill Interamericana Editores S.A.

Jimenéz, T. I. (2011). Autoestima de Riesgo y Protección: Una Mediación entre el Clima Familiar y el Consumo de Sustancias en Adolescentes. Psychosocial Intervention. 20(1),53-61

Jöreskog, K. G. (1971). Statistical analysis of sets of congeneric tests. Psychometrika, 36, 109-133.

Jurado Cárdenas, D., Jurado Cárdenas, S., López, K., \& Querevalú, B. (2015). Validez de la escala de autoestima de Rosenberg en universitarios de la Ciudad de México. Revista Latinoamericana de Medicina Conductual, 5(1), 18-22.

Lara-Cantú, M. A., Verduzco, M. A., Acevcedo, M. \& Cortés, J. (1993). Validez y confiabilidad del inventario de autoestima de Coopersmith para adultos, en población mexicana. Revista Latinoamericana de Psicología, 25(2), 247-255.

Loli, A., Arias, F., Carpio, J., Arce, J., Reyes, M. \& Anyaco, N. (2014). El esfuerzo laboral, la autoestima, y la salud mental en mujeres trabajadoras de Lima Metropolitana. Revista de investigación en psicología, 17(1), 139-155.

Martínez, R. (1995). Psicometría: teoría de los test psicológicos y educativos. Madrid: Síntesis.
McDonald, R. P. (1999). Test theory: A unified treatment. Mahwah: Lawrence Erlbaum Associates, Inc.

Medina, A. A. (1998). Autoestima y rendimiento académico de grado (Tesis de maestría, Universidad Nacional Autónoma de México). Recuperado de http://132.248.9.195/pdbis/265538/Index.html

Méndez, D. (2015). La autoestima y su relación con la agresividad que presentan los adolescentes de 15 a 17 años de edad. Ecuador: Universidad de Ecuador.

Messick, S. (1989). Validity. En R. L. Linn (Ed.), Educational measurement (pp. 13-103). New York: Macmillan.

Messick, S. (1996). Standards-based score interpretation: Establishing valid grounds for valid inferences. Washington DC: Government Printing Office.

Montero, E. (2000). La teoría de respuesta a los ítems: Una moderna alternativa para el análisis psicométrico de instrumentos de medición. Revista de Matemática: Teoría y Aplicaciones, 7(1-2), 217-228.

Montoya, M. Á., \& Sol, C. E. (2001). Autoestima: Estrategias para vivir mejor con técnicas de PNL y desarrollo humano. México: Pax.

Muñiz, J. \& Fonseca-Pedrero, E. (2019). Diez pasos para la construcción de un test. Psicothema, 31(1), 7-16.

Ochoa, D., Flores, M., Borbón, P., Peña, E. \& Zazueta, G. (2018). Agresividad, autoestima y rendimiento académico en estudiantes de secundaria mexicanos. La Habana, Cuba: Asociación latinoamericana de Psicología de la salud.

Ortega, O., Mínguez, R. \& Rodes, M. L. (2001). Autoestima Un nuevo concepto y su medida. Ediciones Universidad de Salamanca. 12(1) 46-66.

Orth, U. \& Robins, R.W. (2008). Low self-esteem prospectively predicts depression in adolescence and young adulthood. Journal of Personality and Social Psychology, 95(3), 695708.

Pope, A. W., Mchale, S. M. \& Craighead, W. E. (1988). Selfesteem enhancement with children and adolescents. New York: Pergamon Press.

Raffini, J. (1998). 100 maneras de incrementar la motivación en clase. España: Troquel.

Reidl, L. (1981). Estructura factorial de la autoestima de mujeres del sur del Distrito Federal. Revista Latinoamericana de Psicología Social, 1(2), 273-288.

Riso, W. (2006). Terapia cognitiva. Fundamentos teóricos y conceptualización del caso clínico. Bogotá: Grupo Editorial Norma.

Rojas-Barahona, C. A., Zegers, P. B. \& Förster, C. (2009). La escala de autoestima de Rosenberg: Validación para Chile en una muestra de jóvenes adultos, adultos y adultos mayores. Revista médica de Chile, 137(6), 791-800.

Rosenberg, M. (1965). Society and the adolescent self-image. Princeton, NJ: Princeton University Press.

Schmitt, N. (1996). Uses and abuses of coefficient alpha. Psychological Assessment, 8(4), 350-353. Recuperado de http://ist_socrates.berkely.edu/ maccoun/pp279_schmittpdf

Serrano A. (2013). Diseño y validación de un cuestionario para medir la autoestima infantil. Publicaciones UCO.

Sierra, R. (2001). Técnicas de investigación social: Teoría y Ejercicios. Madrid: Paraninfo S.A.

Tovar, M. \& Zavarce, B. (1992). Análisis psicométrico exploratorio de la escala de autoestima para niños de Alice Pope (Tesis de licenciatura no publicada). Universidad Católica Andrés Bello. 
Trzesniewski, K. H., Donnellan, M. B., Moffitt, T. E., Robins, R. W., Poulton, R. \& Caspi, A. (2006). Low self-esteem during adolescence predicts poor health, criminal behavior, and limited economic prospects during adulthood. Developmental Psychology, 42(2), 381-390.

Wells, L. E. \& Marwell, U. G. (1976). Self-esteem. Berverly Hills, CA: Sage. 